\title{
Antimicrobial activity of nano cerium oxide (IV) (CeO2) against Streptococcus mutans
}

\author{
Carlos Christiano Lima dos Santos ${ }^{1}$, Isabela Albuquerque Passos Farias ${ }^{1}$, Allan de Jesus dos Reis Albuquerque ${ }^{1 *}$, \\ Patrícia Maria de Freitas e Silva ${ }^{2}$, Giselle Medeiros da Costa One ${ }^{1}$, Fabio Correia Sampaio ${ }^{1}$ \\ From 5th Congress of the Brazilian Biotechnology Society (SBBIOTEC) \\ Florianópolis, Brazil. 10-14 November 2013
}

\section{Background}

Cerium oxide $\left(\mathrm{CeO}_{2}\right)$ is a technologically important material due to its properties and applications in several areas that range from engineering to biological sciences. Despite the hydrothermal microwave method versatility, its crystallization kinetics has low speed when the processing temperatures are below $300^{\circ} \mathrm{C}$ which are the desired conditions for soft chemistry processes [1,2]. At lower temperatures it was found that this material has antimicrobial activity against several bacteria, including E. coli, B. subtilis, Shewanellaoneidensis and Pseudokirchneriella subcapitata, destroying microrganisms cell walls by probable action of reactive oxygen species [3]. When nanoparticles of $\mathrm{CeO}_{2}$ crystals are synthesized (IV), the antimicrobial activity can be better controlled and its spectrum of applications expanded.

\section{Methods}

In this work, cerium oxide nanoparticles (IV) were synthesized by the hydrothermal method, assisted by microwave, with a $150^{\circ} \mathrm{C}$ temperature, approximately, at intervals of 10,15 and 20 minutes. Their structural, morphological and microbiological characteristics were studied by $x$-ray diffraction (XRD), high-resolution electronic scanning microscopy, (FEG-SEM), electronic microscopy of transmission (TEM), BET method, infrared spectroscopy (IR), resazurin, spectrophotometry, fluorescence and agar diffusion.

\section{Results}

All XRD samples showed peaks corresponding to planes

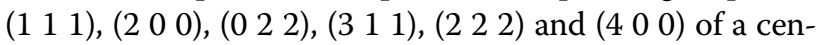
tered face cube, fluorite, attributed to $\mathrm{CeO} 2$ (I) according

${ }^{1}$ Federal University of Paraiba, João Pessoa, Brasil

Full list of author information is available at the end of the article to law JCPDS 34-0394. Broad reflection peaks were clearly visible, demonstrating that the crystal size is small and must be in the nanoscale dimension, which indicates the efficiency of the method for obtaining this nanostructured material. Infrared spectra showed a band of vibration between 700 and $500 \mathrm{~cm}-1$ related to the vibration of the metal- oxygen $(\mathrm{Ce}-\mathrm{O})$ and other results. Their surface areas were approximately $200 \mathrm{~m}^{2} / \mathrm{g}$ with around particle sizes of $5 \mathrm{~nm}$. Micrographs showed different sizes and shapes of clusters. Microbiological tests against Streptococcus mutans for the containing nano cerium oxide (IV) composite in $\mathrm{ZnO}$ at $10 \%$ (diluted in BHI- broth) showed antibacterial effect in minimum inhibitory concentration of $0.22 \mathrm{mg} / \mathrm{mL}$.

\section{Conclusions}

The results showed the direct influence of the synthesis method employed on the morphology and size of nanoparticles cerium oxide (IV) obtained. Nano cerium oxide (IV) seems to be a material of great potential for use against $S$. mutans (a dental bacteria) responsible for cariogenic process due to its purity and particle size. The matching results among the tests employed in biological assays showed that the techniques of fluorescence, spectrophotometry, resazurin and fluorescence did not suffer reagent interference as may eventually occur with some products of natural origin. The dental composite consisting of odontologic $\mathrm{ZnO}$ and nanometer $\mathrm{CeO}_{2}$ in the proportion of $10 \%$ showed superior antimicrobial properties when compared to the standard used (dental zinc oxide + eugenol).

\section{Acknowledgements}

Laboratory of Oral Biology. 


\section{Authors' details}

${ }^{1}$ Federal University of Paraiba, João Pessoa, Brasil. ${ }^{2}$ State University of Paraiba, João Pessoa, Brasil.

\section{Published: 1 October 2014}

\section{References}

1. Komarneni S: Nanophase materials by hydrothermal, microwavehydrothermal and microwave-solvothermal methods. Current Science 2003, 85:1730-1734.

2. Deus RC, Cilense M, Foschini CR, Ramirez MA, Longo E, Simões AZ: Influence of mineralizer agents on the growth of crystalline CeO2nanospheres by the microwave-hydrothermal method. Journal of Alloys and Compounds 2013, 550:245-251.

3. Santos CL, Albuquerque AJR, Sampaio FC, Keyson D: Nanomaterials with Antimicrobial Properties: Applications in Health Sciences. In Microbial pathogens and strategies for combating them: science, technology and education. Volume 4. Microbiology Book Series;Formatex Research Center. Badajoz, Spain 2013.

doi:10.1186/1753-6561-8-S4-P48

Cite this article as: dos Santos et al:: Antimicrobial activity of nano cerium oxide (IV) (CeO2) against Streptococcus mutans. BMC Proceedings 2014 8(Suppl 4):P48.

\section{Submit your next manuscript to BioMed Central} and take full advantage of:

- Convenient online submission

- Thorough peer review

- No space constraints or color figure charges

- Immediate publication on acceptance

- Inclusion in PubMed, CAS, Scopus and Google Scholar

- Research which is freely available for redistribution

Submit your manuscript at www.biomedcentral.com/submit
C Biomed Central 